\title{
Chemical and Phenotypic Characteristics of Flavobacterium thalpophilum Compared with Those of Other Flavobacterium and Sphingobacterium Species
}

\author{
S. B. DEES,* G. M. CARLONE, D. HOLLIS, AND C. W. MOSS \\ Centers for Disease Control, Center for Infectious Diseases, Division of Bacterial Diseases, Atlanta, Georgia 30333
}

\begin{abstract}
Seven strains of Flavobacterium thalpophilum which were isolated from clinical sources were compared with the type strains of Sphingobacterium mizutae and seven species of Flavobacterium. These 15 strains were examined for 11 biochemical characteristics; minor phenotypic variations were observed for the 7 strains of $F$. thalpophilum. All 15 strains were characterized by four major cellular fatty acids (13-methyltetradecanoate, 2-hydroxy-13-methyltetradecanoate, 3-hydroxy-15-methylhexadecanoate, and a monounsaturated 16-carbon straight-chain acid). Sphingophospholipid long-chain bases were detected in all strains of $F$. thalpophilum but were not detected in Flavobacterium balustinum, Flavobacterium breve, Flavobacterium indologenes, Flavobacterium meningosepticum, or Flavobacterium odoratum. F. thalpophilum, Flavobacterium multivorum, Flavobacterium spiritivorum, and $S$. mizuate contained major amounts of menaquinone 7 but no menaquinone 6 , whereas $F$. balustinum, $F$. breve, $F$. indologenes, $F$. meningosepticum, and $F$. odoratum contained major amounts of menaquinone 6 but no menaquinone 7 . The phenotypic and chemical characteristics of $F$. thalpophilum indicate a close taxonomic relationship with $F$. multivorum, $F$. spiritivorum, and $S$. mizutae.
\end{abstract}

Recently, a new species of Flavobacterium, Flavobacterium thalpophilum, was described by Holmes et al. (10). The strains comprising this species were gram-negative, yellowpigmented, aerobic, nonsporeforming, nitrate-reducing, nonmotile rods which grew at 37 and $42^{\circ} \mathrm{C}$. The guanine-pluscytosine $\mathrm{G}+\mathrm{C}$ contents of the deoxyribonucleic acids (DNAs) of these strains were $45.0 \pm 0.8 \mathrm{~mol} \%$ (10), whereas all previously recognized Flavobacterium species had $\mathrm{G}+\mathrm{C}$ contents between 31 and 42 mol\% (10-13). Phenotypic characteristics and DNA-DNA relatedness studies showed that the $F$. thalpophilum strains constituted a single species (10). However, the phenotypic characteristics were too similar to those of existing Flavobacterium species to warrant creation of a new genus. Thus, to include $F$. thalpophilum in the genus Flavobacterium, Holmes et al. expanded the upper limit of the $\mathrm{G}+\mathrm{C}$ content range of the genus to approximately $46 \mathrm{~mol} \%$ (10).

Before $F$. thalpophilum was described, Yabuuchi et al. (26) proposed the genus Sphingobacterium for two species of Flavobacterium (Flavobacterium multivorum and Flavobacterium spiritivorum) and a newly recognized species (Sphingobacterium mizutae). All of the strains examined contained sphingophospholipids and had $\mathrm{G}+\mathrm{C}$ contents of approximately 40 to $42 \mathrm{~mol} \%(10,26,29)$. Phenotypic characteristics and DNA-DNA relatedness studies separated these strains into three species, each of which was distinct from other flavobacteria. Although all three sphingobacteria had $\mathrm{G}+\mathrm{C}$ contents within the range described for previously recognized Flavobacterium species, generic assignments were based predominantly on the presence of relatively large concentrations of sphingophospholipids.

In this investigation, we compared the phenotypic characteristics and isoprenoid quinone, sphingolipid, and cellular fatty acid compositions of $F$. thalpophilum with those of other Flavobacterium and Sphingobacterium species. Although two of the species in this report each have two genus names, no taxonomic recommendations are proposed.

\footnotetext{
* Corresponding author.
}

\section{MATERIALS AND METHODS}

Cultures. The following strains of $F$. thalpophilum were obtained from the culture collection of the Special Bacterial Pathogens Laboratory, Centers for Disease Control: strains $\mathrm{KC} 1671^{\mathrm{T}}$ (= K1173 ${ }^{\mathrm{T}}$; T = type strain), 8291, B5832, C499, $\mathrm{E} 8209, \mathrm{KC} 1670(=\mathrm{K} 997)$, and $\mathrm{KC} 1672(=\mathrm{K} 1232)$. The sources from which these strains were isolated have been described previously by Holmes et al. (10). We also studied the following type strains of eight additional species, four of which originated from the Special Bacterial Pathogens Laboratory: Flavobacterium breve National Collection of Type Cultures strain NCTC $11099^{\mathrm{T}}$, Flavobacterium odoratum NCTC $11036^{\mathrm{T}}$, Flavobacterium balustinum NCTC $11212^{\mathrm{T}}$, S. mizutae American Type Culture Collection strain ATCC $33299^{\mathrm{T}}$, Flavobacterium indologenes $\mathrm{CDC} 3716^{\mathrm{T}}(=$ ATCC $17898^{\mathrm{T}}=\mathrm{NCTC} 10796^{\mathrm{T}}$ ), Flavobacterium meningosepticum CDC $14^{\mathrm{T}}\left(=\right.$ ATCC $13253^{\mathrm{T}}=$ NCTC $\left.10016^{\mathrm{T}}\right), F$. multivorum CDC B5533 ${ }^{\mathrm{T}}\left(=\right.$ ATCC $33613^{\mathrm{T}}=$ NCTC $\left.11343^{\mathrm{T}}\right)$, and $F$. spiritivorum CDC E7288 $\left(=\right.$ ATCC $33861^{\mathrm{T}}=$ NCTC $\left.11386^{\mathrm{T}}\right)$. $F$. multivorum and $F$. spiritivorum are also known as $S$. multivorum and $S$. spiritivorum, respectively (26).

Culture conditions. All cultures except $F$. balustinum cultures were grown on heart infusion agar plates supplemented with $5 \%$ defibrinated rabbit blood at $35^{\circ} \mathrm{C}$ for $24 \mathrm{~h}$ in a candle extinction jar; F. balustinum was grown at $25^{\circ} \mathrm{C}$. The cells used to inoculate biochemical tests were grown on heart infusion agar slants and in heart infusion broth. For all other analyses, heart infusion broth was inoculated with a single colony and incubated for $24 \mathrm{~h}$. Then approximately $0.1 \mathrm{ml}$ of the broth culture was spread onto heart infusion agar plates supplemented with $5 \%$ defibrinated rabbit blood and incubated as before. Cells were scraped from the plates (after approximately $1 \mathrm{ml}$ of sterile water was added), placed into a tube ( 20 by $150 \mathrm{~mm}$ ) with a Teflon-lined cap, and stored at $-20^{\circ} \mathrm{C}$ until chemical analysis. Sufficient cell mass for each strain was obtained by harvesting growth from five plates ( 15 by $100 \mathrm{~mm}$ ) for quinones, six plates for sphingolipids, and one plate for cellular fatty acids.

Phenotypic characteristics. All 15 strains were examined by using biochemical tests and conditions employed in the 
Special Bacterial Pathogens Laboratory, Centers for Disease Control, for the study of microorganisms submitted for identification $(5,6,15,20-22)$.

Cellular fatty acid extraction. Cells harvested from one heart infusion agar plate supplemented with $5 \%$ defibrinated rabbit blood were saponified by adding $4 \mathrm{ml}$ of $15 \% \mathrm{NaOH}$ in $50 \%$ aqueous methanol and heating at $100^{\circ} \mathrm{C}$ for $30 \mathrm{~min}$. Methyl esters of the fatty acids were formed by adding $7 \mathrm{ml}$ of $25 \% \mathrm{HCl}$ in methanol to each cooled hydrolysate, and the contents were again heated to $100^{\circ} \mathrm{C}$ and held for $15 \mathrm{~min}$. The fatty acid methyl esters were then extracted with $10 \mathrm{ml}$ of diethyl ether-hexane (1:1) (nanograde; Mallinckrodt, Paris, Ky.). After vigorous mixing, the organic (top) layer was removed, and the extraction step was repeated. The organic layers from both extractions were combined and reduced in volume (ca. $0.5 \mathrm{ml}$ ) by evaporation under a gentle stream of nitrogen. An equal volume of phosphate buffer $(\mathrm{pH} 11.0)$ was then added, the sample was mixed, and the organic layer containing the methyl esters was removed to a tube (13 by $100 \mathrm{~mm}$ ) for subsequent analysis.

GLC of cellular fatty acids. Fatty acid methyl esters $(0.5 \mu \mathrm{l}$ split 50:1) were analyzed by using a model 3700 hydrogen flame ionization gas chromatograph (Varian Instruments, Palo Alto, Calif.) equipped with a fused-silica capillary column ( $50 \mathrm{~m}$ by $0.2 \mathrm{~mm}$ [inside diameter]) containing OV-1 as the stationary support; data were recorded with a model 3390A electronic integrator (Hewlett-Packard, Avondale, $\mathrm{Pa}$.). The conditions used for gas-liquid chromatography (GLC) analysis have been described previously (18). Cellular fatty acids were identified by comparing retention times with the retention times of authentic standards (Alltech Associates, Inc., Applied Science Div., State College, Pa.; Supelco, Bellefonte, $\mathrm{Pa}$.) before and after sample acetylation and hydrogenation (8). GLC-mass spectrometry (16) and a mathematical plot of carbon number and retention time were also used to support the identification of both branchedchain and straight-chain hydroxy acids when standards were not commercially available.

Determination of sphingolipid long-chain bases. The methods used for hydrolysis and extraction of sphingolipid bases from whole cells were those described by Yabuuchi et al. (28) and Yano et al. (30). Briefly, the cell growth from six heart infusion agar plates were removed and divided equally into three tubes ( 20 by $150 \mathrm{~mm}$ ) with Teflon-lined caps. The cells in each tube were hydrolyzed by adding $10 \mathrm{ml}$ of $25 \%$ $\mathrm{HCl}$ in methanol, heating to $60^{\circ} \mathrm{C}$, and holding for $20 \mathrm{~h}$. After cooling, the acid-hydrolyzed cells were extracted two times with $10-\mathrm{ml}$ portions of a 1:1 mixture of diethyl ether-hexane, and the diethyl ether-hexane layer was discarded. The aqueous layer was adjusted to a $\mathrm{pH}$ of 11 to 12 by adding $\mathrm{NaOH}$ pellets, allowed to stand for $5 \mathrm{~min}$, and then extracted twice with $10 \mathrm{ml}$ of diethyl ether-hexane. The total $20-\mathrm{ml}$ volume of diethyl ether-hexane from each tube, which contained long-chain bases, was transferred to a beaker, reduced in volume to approximately $1 \mathrm{ml}$ under a gentle stream of nitrogen, and transferred to a tube $(13$ by $100 \mathrm{~mm})$. For thin-layer chromatography (TLC), the 1-ml volumes from each of two tubes were combined and evaporated to 0.1 $\mathrm{ml}$ for application to TLC plates. The long-chain bases in the third tube were converted to their trimethylsilyl ether derivatives by adding $50 \mu \mathrm{l}$ of Sil Prep reagent (Alltech Associates). The tube was allowed to stand at room temperature for $15 \mathrm{~min}$, and $1 \mu \mathrm{l}$ of the resulting trimethylsilyl derivative was used for GLC analysis.

TLC of sphingolipid long-chain bases. Ether extracts containing alkaline-hydrolyzed sphingolipid long-chain bases were developed (ca. $50 \mu \mathrm{l})$ on activated $\left(30 \mathrm{~min}, 110^{\circ} \mathrm{C}\right)$ silica gel thin-layer plates (Adsorbosil 5; Alltech Associates) with a chloroform-methanol-water $(65: 25: 4)$ solvent system (28). Development of the bases was complete in $45 \mathrm{~min}$. Authentic dihydrosphingosine (Calbiochem-Behring, La Jolla, Calif.) and alkaline-hydrolyzed ether extracts of $F$. multivorum $\mathrm{CDC} \mathrm{B}_{5533^{\mathrm{T}}}$ were used as controls on each plate. Long-chain bases were visualized as dark blue areas after the plates were sprayed with a ninhydrin solution $(0.2 \%$ in acetone).

GLC of long-chain bases. Trimethylsilyl derivatives of long-chain bases $(1 \mu \mathrm{l})$ were analyzed with a $3 \% \mathrm{OV}-101$ packed column ( $3.05 \mathrm{~m}$ by $6.71 \mathrm{~mm}$ [inside diameter]); peaks were recorded with a model $3390 \mathrm{~A}$ electronic integrator. Long-chain bases ranging from 15 to 19 carbons long eluted within 20 min with the column temperature at $220^{\circ} \mathrm{C}$. Tentative identification of unknown bases was made by comparing retention times with the retention times of an authentic dihydrosphingosine standard and of those bases previously reported in $F$. multivorum (30); structural identity was confirmed by GLC-mass spectrometry (30).

Isoprenoid quinone extraction. Quinones were extracted from saponified cells by a modification of the procedure of Abe et al. (1), as previously described (14). The cell mass from five heart infusion agar plates supplemented with $5 \%$ defibrinated rabbit blood was harvested (ca. $0.5 \mathrm{~g}$, wet weight) and transferred to a tube $(20$ by $150 \mathrm{~mm})$ with a Teflon-lined cap. The cells were saponified by adding $3 \mathrm{ml}$ of a $1 \%(\mathrm{wt} / \mathrm{vol})$ pyrogallol solution in methanol and $0.2 \mathrm{ml}$ of $50 \%$ aqueous $\mathrm{KOH}$. The mixture was heated to $100^{\circ} \mathrm{C}$, held for $10 \mathrm{~min}$, and cooled to room temperature. A 1-ml volume of distilled water and $5 \mathrm{ml}$ of diethyl ether-hexane (1:1) were added, the mixture was vigorously shaken for $5 \mathrm{~min}$ on a wrist action shaker (Burrell Corp., Pittsburgh, Pa.), and then the preparation was centrifuged at $1,200 \times g$ for $10 \mathrm{~min}$. The upper organic layer was recovered, and the lower aqueous layer was extracted two additional times. The combined organic layers were evaporated to dryness under a gentle stream of nitrogen, and $0.5 \mathrm{ml}$ of methanol was added. The identity of the extracted quinones was confirmed by various analytical techniques, using authentic quinone standards for comparison (ubiquinones Q-6, Q-7, Q-9, and Q-10 from Sigma Chemical Co., St. Louis, Mo.; menaquinone 3 [MK-3] to MK-10 from Hoffmann-LaRoche Co., Basle, Switzerland). Under the conditions described above, a yellow pigment was extracted from the cells along with quinones.

TLC of quinones. Authentic quinone standards and wholecell extracted quinones in methanol $(20 \mu \mathrm{l})$ were developed on type $\mathrm{K}_{18} \mathrm{~F}$ reverse-phase TLC (RPTLC) plates (Whatman Chemical Separation Div., Clifton, N.J.) with a methanolacetone $(50: 50)$ solvent system. All of the reagents used were of nanograde quality (Mallinckrodt). Development was completed in approximately $35 \mathrm{~min}$; the separated quinones were detected with 254-nm ultraviolet (UV) light (4). The yellow pigment extracted along with the quinones was developed with this system and was observed with white light.

Ubiquinones were separated from menaquinones when standards and whole-cell extracts were developed on activated $\left(100^{\circ} \mathrm{C}, 30 \mathrm{~min}\right)$ silica gel (TLC) plates (Whatman Chemical Separation Div.) with a hexane-diethyl ether $(85: 15)$ solvent system. Development was complete in approximately $60 \mathrm{~min}$, and the quinones were detected as described above.

HPLC of quinones. Authentic quinone standards and wholecell extracted quinones were dissolved in methanol and 
TABLE 1. Phenotypic characteristics of Flavobacterium and Sphingobacterium species not previously reported ${ }^{a}$

\begin{tabular}{|c|c|c|c|c|c|c|c|c|c|c|}
\hline Test $^{b}$ & $\begin{array}{c}F \\
\text { thalpophilum } \\
\mathrm{KC1}^{2} \\
\text { (61 }\end{array}$ & $\begin{array}{c}F \\
\text { thalpophilum } \\
\text { (6 strains) }\end{array}$ & $\begin{array}{c}S . \\
\text { mizutae } \\
\text { ATCC } \\
33299^{\mathrm{T}}\end{array}$ & $\begin{array}{c}F . \\
\text { multivorum } \\
\text { CDC } \\
{\mathrm{B} 5533^{\mathrm{T}}}^{\mathrm{T}}\end{array}$ & $\begin{array}{c}F . \\
\text { spiritivorum } \\
\text { CDC } \\
\text { E7288 }\end{array}$ & $\begin{array}{c}F . \\
\text { breve } \\
\text { NCTC } \\
11099^{\mathrm{T}}\end{array}$ & $\begin{array}{c}F . \\
\text { indologenes } \\
\text { CDC } 3716^{\mathrm{T}}\end{array}$ & $\begin{array}{l}F . \text { meningo- } \\
\text { septicum } \\
\text { CDC } 14^{\mathrm{T}}\end{array}$ & $\begin{array}{c}F . \\
\text { odoratum } \\
\text { NCTC } \\
11036^{\mathrm{T}}\end{array}$ & $\begin{array}{c}F . \\
\text { balustinum } \\
\text { NCTC } \\
11212^{\mathrm{T}}\end{array}$ \\
\hline TSI slant, acid ${ }^{d}$ & + & + & - & $(W)$ & (W) & - & - & - & - & - \\
\hline TSI butt, acid & $(\mathrm{W})$ & $(\mathrm{W})$ & - & (W) & - & - & W & W & - & W \\
\hline Litmus milk & $(\mathrm{P}, \mathrm{IR})$ & $\mathrm{V}^{e}$ & (A) & - & - & $(\mathrm{P}, \mathrm{IR})$ & $\mathrm{P}$ & $(\mathrm{P}, \mathrm{IR})$ & $\mathbf{P}$ & $\mathrm{P}$ \\
\hline Deoxyribonuclease ${ }^{f}$ & + & + & & & & & & & & \\
\hline Flexirubin pigment ${ }^{f}$ & - & - & & & & & & & & \\
\hline $\begin{array}{l}\text { Assimilation of: } \\
\text { Acetamide } f\end{array}$ & - & - & & & & & & & & \\
\hline Serine & + & + & + & + & - & - & + & + & - & $(+)$ \\
\hline $\begin{array}{l}\text { Acid produced in } \\
\text { OF medium: }\end{array}$ & & & & & & & & & & \\
\hline Erythritol & - & $\mathrm{V}^{h}$ & - & - & - & - & - & - & - & - \\
\hline Melezitose ${ }^{f}$ & W & $\mathrm{V}^{i}$ & & & & & & & & \\
\hline Starch & + & + & - & + & - & + & + & - & - & - \\
\hline
\end{tabular}

${ }^{a}+$, Positive in 1 to 2 days; - negative through 7 days; V, variable; $P$, peptonization; $A$, weak acid; IR, indicator reduction; W, weak positive. The parentheses indicate that the reaction was delayed 3 to 7 days.

${ }^{b}$ In addition, all strains hydrolyzed L-alanine-4-nitroanilide hydrochloride, gave a positive string test with $3 \% \mathrm{KOH}$, and grew in nutrient broth containing no $\mathrm{NaCl}$. No strain grew in nutrient broth supplemented with $6 \% \mathrm{NaCl}$ or assimilated $d$-tartrate.

${ }^{c}$ Grown at $25^{\circ} \mathrm{C}$

${ }^{d}$ TSI, Triple sugar iron.

e Strain C499 was positive for peptonization and indicator reduction at 3 to 7 days; there was no change with the other five strains.

${ }^{f}$ Data for all strains except the $F$. thalpophilum strains have been reported previously $(10,12,23,26)$.

${ }^{8}$ Acid production by $F$. odoratum in OF media was tested at 35 and $25^{\circ} \mathrm{C}$ since growth was minimal at $35^{\circ} \mathrm{C}$.

${ }^{h}$ Strain K1232 was positive after 3 to 7 days.

${ }^{i}$ Strain K1232 was negative at 7 days.

separated by high-performance liquid chromatography (HPLC) as previously described (19). The HPLC system used was composed of a model SP8700 solvent delivery pump (Spectra-Physics, Inc., San Jose, Calif.) equipped with a model 7120 injector containing a $20-\mu l$ sampling loop (Rheodyne, Inc., Cotati, Calif.); a model 1220 variable-wavelength detector (LDC Div., Milton Roy Co., Riviera Beach, Fla.); a model 56 strip chart recorder (Perkin-Elmer Corp., Norwalk Conn.); and a $\mu$ Bondapak C-18 reverse-phase column (300 by $3.9 \mathrm{~mm}$; particle size, $10 \mu \mathrm{m}$; Waters Associates, Inc., Milford, Mass.). Quinones were chromatographed in a gradient system composed of methanol, isopropanol, and water (75:25:5) with a flow rate of $1 \mathrm{ml} / \mathrm{min}$. The solvent composition changed to $35: 65: 0$ in a linear manner at $25 \mathrm{~min}$. Menaquinones and ubiquinones were monitored at 248 and $275 \mathrm{~nm}$, respectively, and were collected when required. The purity of the isolated quinones was determined by performing HPLC and RPTLC again, and the structural identity was confirmed by mass spectrometry $(4,14)$.

Absorption spectrophotometry. All spectroscopic measurements were made with a Beckman model 25 scanning UV-visible spectrophotometer and Beckman recorder, using 1-ml cuvettes. Menaquinones purified by HPLC or RPTLC (eluted with acetone from TLC plates) were evaporated to dryness and dissolved in absolute ethanol. Reduction of authentic standards or HPLC-purified menaquinones was achieved by adding $5 \mu \mathrm{l}$ of an aqueous solution of $\mathrm{KBH}_{4}(5$ $\mathrm{mg} / \mathrm{ml}$; kept at $0^{\circ} \mathrm{C}$ ) to $1 \mathrm{ml}$ of the ethanolic solution containing $5 \mu \mathrm{l}$ of $0.5 \mathrm{M}$ sodium acetate buffer ( $\mathrm{pH}$ 5.2) (4). The spectra of ethanolic solutions of menaquinones extracted from flavobacteria and sphingobacteria were recorded at room temperature from 220 to $340 \mathrm{~nm}$.

The visible absorption spectrum of the pigment extracted from $F$. thalpophilum and separated by HPLC and RPTLC was recorded from 360 to $600 \mathrm{~nm}$ as described above by using hexane or absolute ethanol as the solvent $(3,24)$.
Alkaline-hexane or alkaline-ethanol (up to $50 \mu \mathrm{l}$ ) was added to the pigment solution, and the spectrum was recorded again in order to observe any bathochromic spectral shift. A carotenoid pigment reference spectrum was recorded as described above by using $\beta$-carotene (Eastman Kodak Co., Rochester, N.Y.).

Mass spectrometry. Mass spectrometry data were obtained with a Du Pont mass spectrometer equipped for both electron impact and chemical ionization (14).

\section{RESULTS AND DISCUSSION}

Phenotypic characteristics. Flavobacterium and Sphingobacterium species are differentiated from one another by a variety of biochemical characteristics $(10,12,23,26)$. The morphological and phenotypic characteristics of all of the bacterial strains examined in this investigation were in agreement with those described in previously published reports. Table 1 contains additional phenotypic characteristics for these strains.

Phenotypic variation was observed in the seven strains of $F$. thalpophilum examined (Table 1). Two strains, including the type strain, peptonized litmus milk and reduced the indicator between 3 and 7 days, whereas the other five strains gave no reaction. Only one strain produced acid from erythritol and alkali from melezitose by 7 days.

A pale pink color was observed in the xylene layer of the indole test (data not shown) with the type strain of $S$. mizutae; this test was repeated several times since Yabuuchi et al. (26) reported a negative result. The color occurred only in the area where the Erhlich reagent first made contact with the xylene. There was no pink color at the interface of the xylene and the Erhlich reagent, where the typical indole reaction occurs. Until this observation is investigated further, we interpret this test to be negative for indole production.

Cellular fatty acid composition. Figure 1 shows a chromatogram of the cellular fatty acids (as methyl esters) of $F$. 


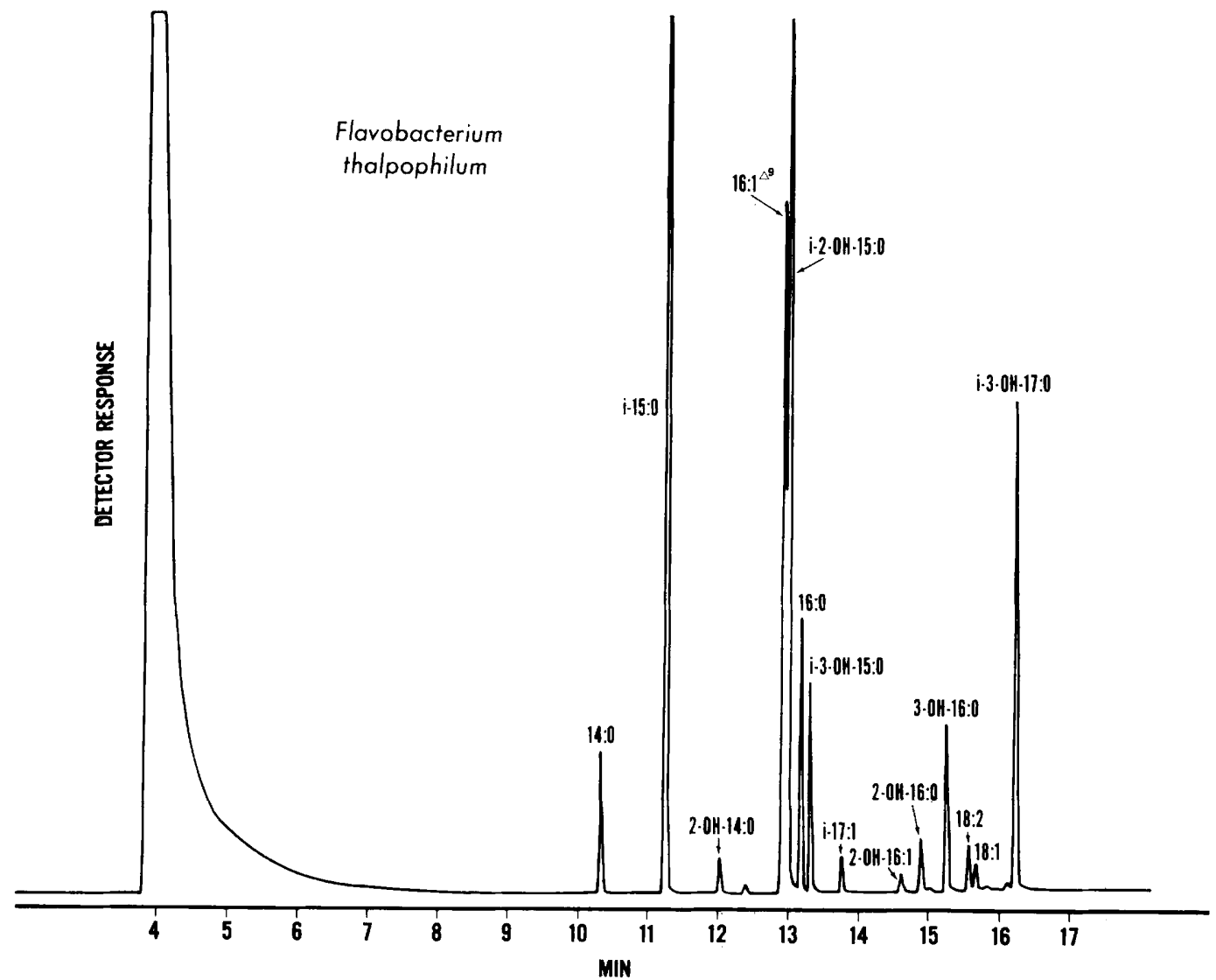

FIG. 1. Gas chromatogram of esterified fatty acids from saponified whole cells of $F$. thalpophilum KC1671 ${ }^{\mathrm{T}}$. The analysis was performed on a fused-silica capillary column ( $50 \mathrm{~m}$ by $0.2 \mathrm{~mm}$ [inside diameter]) with OV-1 as the stationary phase. See Table 2 for peak identification.

thalpophilum $\mathrm{KC1671}{ }^{\mathrm{T}}$ analyzed on a $50-\mathrm{m}$ OV-1 column. The sharpness of the peaks in the chromatogram and the base-line resolution of all components except a monounsaturated 16-carbon straight-chain acid (16:1 acid) and (2-hydroxy-13-methyltetradecanoate (i-2-OH-15:0 acid) illustrate the excellent separating efficiency of the capillary column. Although the 16:1 and i-2-OH-15:0 acids were not resolved, there were sufficient differences in their retention times to permit quantitation with an electronic integrator. On capillary columns less than 50 -m long, we have found that these two components coelute. However, after acetylation, the $\mathrm{i}-2-\mathrm{OH}-15: 0$ acid is converted to the diester derivative, which is then resolved from $16: 1$ acid (27).
The quantitative fatty acid data for each of the seven strains are presented in Table 2 . The values listed in this Table are averages from two or more separate analyses of the organisms processed through the entire procedure of regrowth, saponification, and GLC analysis. The data in Table 2 show that the fatty acid compositions of the seven strains were similar and that each strain was characterized by the presence of the following four major acids: 13-methyltetradecanoate (i-15:0), i-2-OH-15:0 acid, 3-hydroxy-15methylhexadecanoate (i-3-OH-17:0), and a $-16: 1$ acid. The relative amounts of $\mathrm{i}-15: 0$ and $\mathrm{i}-2-\mathrm{OH}-15: 0$ acids in the seven strains ranged from 20 to $36 \%$ and from 22 to $28 \%$, respectively; the only organisms reported to contain similar con-

TABLE 2. Cellular fatty acid compositions of strains of $F$. thalpophilum

\begin{tabular}{|c|c|c|c|c|c|c|c|c|c|c|c|c|c|c|}
\hline \multirow[b]{2}{*}{ Strain } & \multicolumn{14}{|c|}{ Fatty acid composition" } \\
\hline & $14: 0^{b}$ & $\mathrm{i}-15: 0$ & $a-15: 0$ & $16: 1^{j 9}$ & $\underset{\mathrm{O}-15: 0}{2-}$ & $16: 0$ & $\begin{array}{c}3- \\
\mathrm{OH}- \\
\mathrm{i}-15: 0\end{array}$ & $\begin{array}{c}\text { (1)- } \\
\mathrm{i}-17: 1\end{array}$ & $\begin{array}{c}(2)- \\
i-17: 1\end{array}$ & $\begin{array}{c}2- \\
\mathrm{OH}- \\
16: 0\end{array}$ & $\begin{array}{c}3- \\
\mathrm{OH}- \\
16: 0\end{array}$ & $18: 2$ & $18: 1$ & $\begin{array}{c}\text { 3- } \\
\text { OH- } \\
i-17: 0\end{array}$ \\
\hline$\overline{\mathrm{K} 1173^{\mathrm{T}}}$ & $3^{c}$ & 30 & $\mathrm{~T}$ & 19 & 22 & 5 & 4 & $\mathrm{~T}$ & $\mathrm{~T}$ & $\mathrm{~T}$ & 4 & $\mathrm{~T}$ & $\mathrm{~T}$ & 13 \\
\hline K1232 & $\mathrm{T}$ & 36 & 2 & 11 & 26 & 2 & 3 & 2 & $\mathrm{~T}$ & $T$ & $\mathrm{~T}$ & 2 & 2 & 14 \\
\hline K997 & 2 & 27 & $\mathrm{~T}$ & 17 & 25 & 4 & 4 & 2 & $\mathrm{~T}$ & $\mathrm{~T}$ & 3 & 2 & 2 & 12 \\
\hline B5832 & 2 & 28 & $\mathrm{~T}$ & 16 & 26 & 3 & 5 & 2 & 2 & $T$ & 2 & $\mathrm{~T}$ & $\mathrm{~T}$ & 14 \\
\hline E8209 & 2 & 33 & $\mathrm{~T}$ & 12 & 28 & 3 & 3 & 2 & $\mathrm{~T}$ & $\mathrm{~T}$ & 2 & $\mathrm{~T}$ & $\mathrm{~T}$ & 15 \\
\hline 8291 & 4 & 20 & $\mathrm{~T}$ & 21 & 22 & 8 & 3 & $\mathrm{~T}$ & $\mathrm{~T}$ & 3 & 6 & 2 & 2 & 9 \\
\hline
\end{tabular}

a The number to the left of the colon is the number of carbon atoms, and the number to the right of the colon is the number of double bonds. i, iso; a. anteiso; $\mathrm{OH}$, hydroxy: (1), isomer $1 ;(2)$ isomer $2 ; 18: 1$, oleic acid.

${ }^{h}$ Additional fatty acids occurring in trace amounts were $\mathrm{i}-13: 0, \mathrm{i}-15: 1,2-$ and 3-OH-14:0, 15:1, 15:0, i-17:0, 2-OH-16:1, 18:1 (cis-vaccenic), and 18:0 acids.

Values are percentages of total acids: T. trace $(<2 \%)$. 
centrations of these two acids are the sphingobacteria (26, $27)$ and flavobacteria $(9,17,27)$. The relative amount of $16: 1$ acid in $F$. thalpophilum ranged from 11 to $21 \%$, which is similar to the amount found in Sphingobacterium species $(26,27)$ but significantly higher than the amount reported for Flavobacterium species $(9,17)$. Thus, the overall cellular fatty acid composition of $F$. thalpophilum is essentially identical to that of sphingobacteria and differs from the composition reported for flavobacteria species only by containing higher amounts of 16:1 acid(s).

Sphingolipid composition. Using the hydrolysis procedure of Yabuuchi et al. (28) as described above, we detected long-chain bases in each of the seven strains of $F$. thalpophilum but not in strains of $F$. meningosepticum, $F$. breve, $F$. odoratum, $F$. indologenes, and $F$. balustinum. TLC of the alkaline-hydrolyzed extracts from each strain showed one major ninhydrin-positive spot which had an $R_{f}$ value identical to that of branched-chain 17-carbon sphinganin ( $d-17: 0$ branched-chain base), the major long-chain base of $F$. multivorum (30). GLC of the alkaline-extracted fraction also showed $d-17: 0$ branched-chain base as the major long-chain base ( $90 \%$ ), with a GLC retention time identical to that of the $d-17: 0$ branched-chain base of $F$. multivorum. Minor amounts of other long-chain bases were present in each of the seven strains and were tentatively identified by GLC as $d-16: 0$, $d-18: 1, d-18: 0$, and $d-19: 0$ bases. The identities of $d-16: 0$, $d-17: 0$ branched-chain, and $d-18: 0$ bases were confirmed by combined GLC-mass spectrometry of trimethylsilyl derivatives, which showed mass spectra essentially identical to those reported previously for these compounds (30). Each strain of $F$. thalpophilum and the control strain of $F$. multivorum contained significant amounts of long-chain bases, as evidenced by intense ninhydrin-positive spots on TLC and major GLC peaks of trimethylsilyl derivatives, whereas no GLC peaks or ninhydrin-positive spots of longchain bases were detected in any other Flavobacterium species tested.

The results described above differ from those of Asselineau and Pichinoty (2), who reported sphingosine-like compounds in $F$. breve, $F$. odoratum, and $F$. meningosepticum. These workers obtained a crude chloroform-methanol (2:1) extract from whole cells which was subsequently acid hydrolyzed, chromatographed by TLC, and visualized with ninhydrin. Under these conditions Asselineau and Pichinoty detected a ninhydrin-positive spot with an $R_{f}$ value slightly lower than that of C-18 sphingosine; the identity of the compound was not established. In the present study, however, we tested acid-hydrolyzed extracts from whole cells and did not observe long-chain bases, as detected in the alkaline hydrolysates.

Isoprenoid quinone content. The physiological significance and diversity of bacterial quinones makes them a useful characteristic for taxonomy. Ubiquinones are associated with high-potential electron acceptors, such as oxygen and nitrates, whereas naphthoquinones (menaquinones and demethylmenaquinones) use lower-potential electron acceptors, such as fumarate (4). In addition to the type of quinone present, the length and degree of saturation of the isoprenoid side chain are important characteristics for taxonomic classification (7).

One major unsaturated menaquinone, which cochromatographed (as determined by RPTLC and HPLC) with the authentic MK-7 standard, was detected in $F$. thalpophilum, $F$. multivorum, $F$. spiritovorum, and $S$. mizutae, whereas MK-6 was the major menaquinone detected in $F$. balustinum, $F$. breve, $F$. indologenes, $F$. meningosepticum, and $F$.
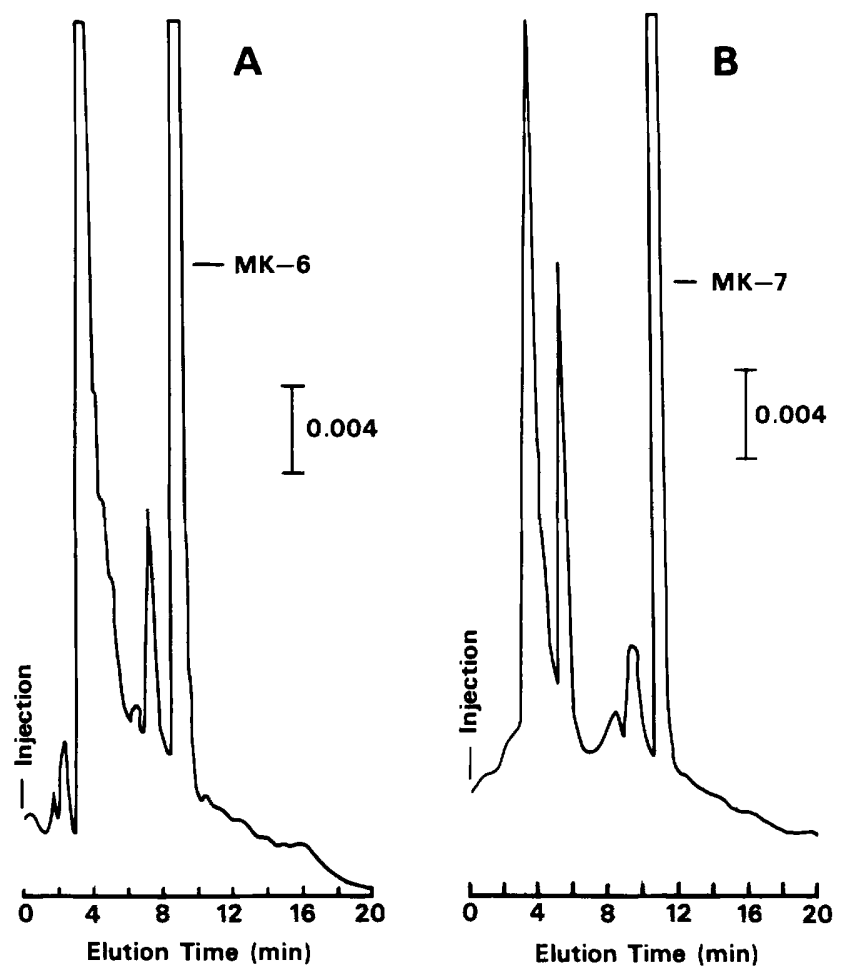

FIG. 2. High-performance liquid chromatograms of menaquinones extracted from whole cells of $F$. breve NCTC $11099^{\mathrm{T}}$ (A) and $F$, thalpophilum $\mathrm{KC} 1671^{\mathrm{T}}(\mathrm{B})$. The menaquinones of $F$. breve and $F$. thalpophilum had elution times of $9.0 \mathrm{~min}$ (MK-6) and $11.0 \mathrm{~min}$ (MK-7), respectively. The $F$. breve peak eluting at $7.8 \mathrm{~min}$ and the $F$. thalpophilum peaks eluting at 5.2 (pigment) and $10.0 \mathrm{~min}$ were not identified.

odoratum. Neither ubiquinones nor demethylmenaquinones were detected. The identities of the menaquinones were confirmed by UV spectrophotometry and mass spectrometry; the molecular ions for MK-6 and MK-7 were at massto-charge ratios of 580 and 648 , respectively. Quinones were separated by RPTLC and HPLC as a function of isoprene unit number $(4,19)$. All standards and test samples were separated by RPTLC within 35 min and by HPLC within 16 min.

The HPLC peaks eluting at 9.0 and 11.0 min contained MK-6 and MK-7, respectively; representative chromatograms are shown in Fig. 2. The other peaks detected were not identified, but were determined not to be quinones. Unidentified compounds which were detected by RPTLC (Table 3) were also found not to be quinones; the whole-cellextracted MK-6 and MK-7 had $R_{f}$ values of $45.1 \times 10^{2}$ and $38.4 \times 10^{2}$, respectively.

Menaquinone absorption spectrum. The oxidized and reduced UV absorption spectrum of an ethanolic solution of quinones extracted from $F$. thalpophilum is shown in Fig. 3. This spectrum is characteristic of menaquinones and is representative of the quinones found in the other flavobacteria and sphingobacteria examined.

The maxima for oxidized menaquinone (Fig. 3, solid line) were at 242 and $248 \mathrm{~nm}$ (benzenoid absorbance) and at 261 and $269 \mathrm{~nm}$ (quinonoid absorbance). Upon reduction with $\mathrm{KBH}_{4}$ (Fig. 3, dashed line), there was a substantial loss of absorbance at 261 and $269 \mathrm{~nm}$ and an increase in absorbance at $245 \mathrm{~nm}$, as previously reported for menaquinones $(4,7)$.

Pigment(s). A yellow pigment that coextracted with cellular quinones was found in all seven strains of $F$. thalpo- 
TABLE 3. Menaquinones and $R_{f}$ values of unidentified compounds detected by RPLTC in Flavobacterium and Sphingobacterium species

\begin{tabular}{|c|c|c|c|}
\hline \multirow{2}{*}{ Species ${ }^{\prime}$} & \multicolumn{2}{|c|}{ Presence of major menaquinones ${ }^{h}$} & \multirow{2}{*}{$\begin{array}{l}\left(R_{f}, \text { values }\right. \\
\left(\times 10^{2}\right) \text { of } \\
\text { unidentified } \\
\text { compounds }\end{array}$} \\
\hline & $\begin{array}{c}\text { MK-6 } \\
\left(R_{f}, 45.1 \times 10^{2}\right)\end{array}$ & $\begin{array}{c}\text { MK-7 } \\
\left(R_{f}, 38.4 \times 10^{2}\right)\end{array}$ & \\
\hline $\begin{array}{l}\text { F. thalpophilum } \\
\text { (7 strains) }\end{array}$ & $-{ }^{d}$ & + & $50.5,71.5^{\prime \prime}$ \\
\hline S. mizutae & - & + & $50.5,71.5$ \\
\hline F. multivorum & - & + & $50.5,71.5$ \\
\hline F. spiritivorum & - & + & $50.5,71.5$ \\
\hline F. balustinum & + & - & 56.5 \\
\hline$F$. breve & + & - & - \\
\hline F. indologenes & + & - & - \\
\hline F. meningosepticum & + & - & 56.8 \\
\hline$F$. odoratum & + & - & - \\
\hline
\end{tabular}

"The strains tested are given in the text and in Table 1.

${ }^{b}$ The chromatographic identities of the major menaquinones were based upon $R_{f}$ values observed with authentic menaquinone standards.

c The unidentified compounds detected by RPTLC were determined not to be quinones when analyzed by HPLC. UV spectrophotometry, and mass spectrometry.

$d+$, Detected;,- not detected.

e A yellow pigment detected with white light was observed at an $R_{f}$ value of $71.5 \times 10^{2}$.

philum and the type strains of $F$. multivorum, $F$. spiritivorum, and $S$. mizutae. This pigment developed at an $R_{f}$ value of $71.5 \times 10^{2}$ as determined by RPTLC (Table 3) and eluted at $5.2 \mathrm{~min}$ as determined by HPLC (Fig. 2B). Only the pigment extracted from $F$. thalpophilum was collected and analyzed. The identity of this pigment was not determined.

The absorption spectra of a previously recorded sample showed no bathochromic spectral shift after the addition of alkali to the hexane-pigment or ethanol-pigment solution (Fig. 4). However, the fine structure observed in the absorp-

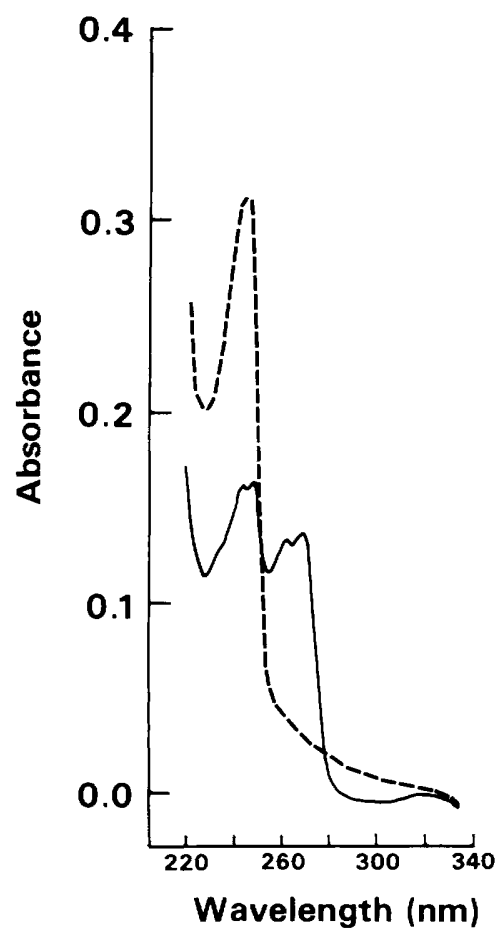

FIG. 3. UV absorption spectra of MK-7 from $F$. thalphophilum $\mathrm{KC} 1671^{\mathrm{T}}$ in absolute ethanol. The solid line is oxidized MK-7, and the dashed line is reduced MK-7.

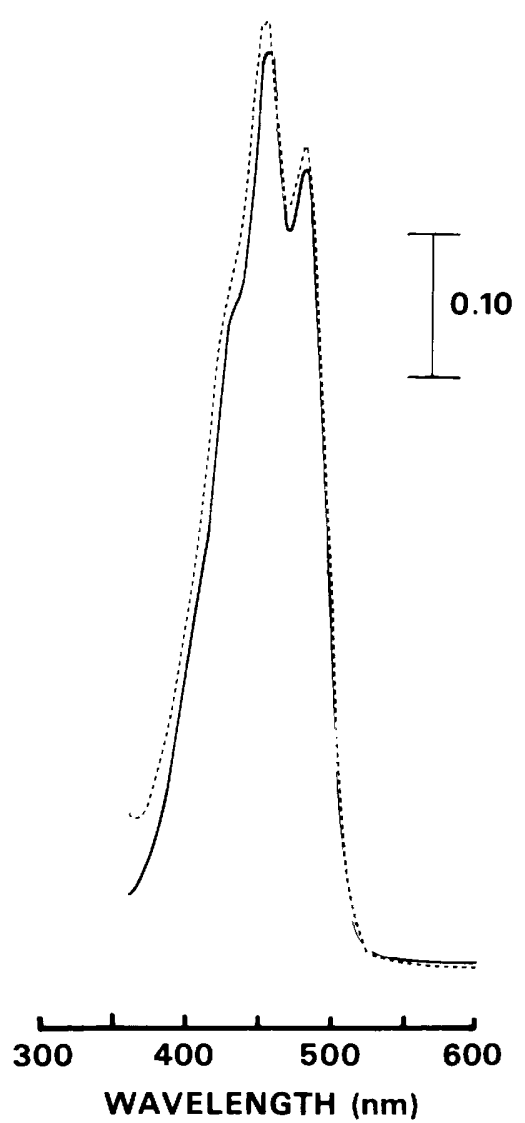

FIG. 4. Visible absorption spectrum of the extracted yellow pigment from $F$. thalpophilum $\mathrm{KC} 671^{\mathrm{T}}$ in absolute ethanol (solid line). A bathochromic spectral shift was not observed upon addition of alkali to the ethanolic solution (dashed line).

tion spectrum is consistent with that of a carotenoid pigment $(3,24)$. This is in contrast to the pigment reported in $F$. breve and $F$. odoratum, which was shown to have an alkaline-catalyzed bathochromic spectral shift and not to be carotenoid in nature $(25)$.

In summary, the cellular fatty acid composition for all strains was essentially identical to the composition of species of Sphingobacterium and differed from the composition reported for Flavobacterium species only by containing higher amounts of 16:1 acid(s). Sphingophospholipids were detected in relatively large amounts in $F$. thalpophilum, $F$. multivorum, $F$. spiritivorum, and $S$. mizutae, whereas the other flavobacteria examined did not contain sphingolipids or contained only trace amounts. These four species also contained MK-7 as the major isoprenoid quinone, and the other flavobacteria contained MK-6.

From the data presented above, it is evident that $F$. thalpophilum, F. multivorum, F. spiritivorum, and S. mizutae should be grouped together. However, taxonomic recommendations concerning the appropriate genus are not made at this time.

\section{ACKNOWLEDGMENT}

We thank Robert E. Weaver for his help in preparing the manuscript.

\section{LITERATURE CITED}

1. Abe, K., K. Ishibashi, M. Ohmae, K. Kawabe, and G. Katsui. 1978. Determination of ubiquinone in serum and liver by high- 
speed liquid chromatograpy. J. Nutr. Sci. Vitaminol. 24:555-567.

2. Asselineau, J., and F. Pichinoty. 1983. Lipid composition of strains of Flavobacterium and Sphingobacterium. FEMS Microbiol. Lett. 20:375-378.

3. Britton, G., and T. W. Goodwin. 1971. Biosynthesis of carotenoids. Methods Enzymol. 18:654-700.

4. Carlone, G. M., and F. A. L. Anet. 1983. Detection of menaquinone- 6 and a novel methyl-substituted menaquinone- 6 in Campylobacter jejuni and Campylobacter fetus subsp. fetus. J. Gen. Microbiol. 129:3385-3393.

5. Carlone, G. M., M. J. Valadez, and M. J. Pickett. 1982. Methods for distinguishing gram-positive from gram-negative bacteria. $\mathrm{J}$. Clin. Microbiol. 16:1157-1159.

6. Centers for Disease Control. 1983. Laboratory methods in special medical bacteriology techniques. Course 8390-C. Centers for Disease Control, Atlanta, Ga.

7. Collins, M. D., and D. Jones. 1981. Distribution of isoprenoid quinone structural types in bacteria and their taxonomic implications. Microbiol. Rev. 45:316-354.

8. Dees, S. B., D. E. Karr, D. Hollis, and C. W. Moss. 1982. Cellular fatty acids of Capnocytophaga species. J. Clin. Microbiol. 16:779-783.

9. Dees, S. B., C. W. Moss, R. E. Weaver, and D. Hollis. 1979. Cellular fatty acid composition of Pseudomonas paucimobilis and groups IIk-2, Ve-1, and Ve-2. J. Clin. Microbiol. 10:206-209.

10. Holmes, B., D. G. Hollis, A. G. Steigerwalt, M. J. Pickett, and D. J. Brenner. 1983. Flavobacterium thalpophilum, a new species recovered from human clinical material. Int. J. Syst. Bacteriol. 33:677-682.

11. Holmes, B., and R. J. Owen. 1979. Proposal that Falvobacterium breve be substituted as the type species of the genus in place of Flavobacterium aquatile and emended description of the genus Flavobacterium: status of the named species of Flavobacterium. Repeat for an Opinion. Int. J. Syst. Bacteriol. 29:416-426.

12. Holmes, B., R. J. Owen, and D. G. Hollis. 1982. Flavobacterium spiritivorum, a new species isolated from human clinical specimens. Int. J. Syst. Bacteriol. 32:157-165.

13. Holmes, B., R. J. Owen, and R. E. Weaver. 1981. Flavobacterium multivorum, a new species isolated from human clinical specimens and previously known as group IIk, biotype 2. Int. J. Syst. Bacteriol. 31:21-34.

14. Karr, D. E., W. F. Bibb, and C. W. Moss. 1982. Isoprenoid quinones of the genus Legionella. J. Clin. Microbiol. 15: 1044-1048.

15. King, E. O. 1964. The identification of unusual pathogenic gram negative bacteria (revised by R. E. Weaver). Centers for Disease Control, Atlanta, Ga.

16. Moss, C. W., and S. B. Dees. 1975. Identification of microorganisms by gas chromatographic-mass spectrometric analysis of cellular fatty acids. J. Chromatogr. 112:595-604.
17. Moss, C. W., and S. B. Dees. 1978. Cellular fatty acids of Flavobacterium meningosepticum and Flavobacterium species group IIb. J. Clin. Microbiol. 8:772-774.

18. Moss, C. W., S. B. Dees, and G. O. Guerrant. 1980. Gas-liquid chromatography of bacterial fatty acids with a fused-silica capillary column. J. Clin. Microbiol. 12:127-130.

19. Moss, C. W., and G. O. Guerrant. 1983. Separation of bacterial ubiquinones by reverse-phase high-performance liquid chromatography. J. Clin. Microbiol. 18:15-17.

20. Negut, M., and G. Hermann. 1975. A comparison of two methods for detecting beta-D-galactosidase. Public Health Lab. 33:190-193.

21. Rarick, H. W., P. S. Riley, and R. Martin. 1978. Carbon substrate utilization studies of some cultures of Alcaligenes denitrificans, Alcaligenes faecalis, and Alcaligenes odorans isolated from clinical specimens. J. Clin. Microbiol. 8:313-319.

22. Riley, P. S., H. W. Tatum, and R. E. Weaver. 1972. Pseudomonas putrefaciens isolated from clinical specimens. Appl. Microbiol. 24:798-800.

23. Shewan, J. M., and T. A. McMeekin. 1983. Taxonomy (and ecology) of Flavobacterium and related genera. Annu. Rev. Microbiol. 37:233-252.

24. Synnove, L.-J., and A. Jensen. 1971. Quantitative determination of carotenoids in photosynthetic tissues. Methods Enzymol. 23:586-602.

25. Weeks, O. B. 1980. Preliminary studies of the pigments of Flavobacterium breve NCTC 11099 and Flavobacterium odoratum NCTC 11036, p. 109-114. In H. Reichenbach and O. B. Weeks (ed.), The Flavobacterium-Cytophaga group. GBF Monograph Series, no. 5. Verlag Chemie, Weinheim.

26. Yabuuchi, E., T. Kaneko, I. Yano, C. W. Moss, and N. Miuoshi. 1983. Sphingobacterium gen. nov., Sphingobacterium spiritivorum comb. nov., Sphingobacterium multivorum comb. nov., Sphingobacterium mizutae sp. nov., and Flavobacterium indologenes sp. nov.: glucose-nonfermenting gram-negative rods in CDC groups IIK-2 and Ilb. Int. J. Syst. Bacteriol. 33:580-598.

27. Yabuuchi, E., and C. W. Moss. 1982. Cellular fatty acid composition of strains of Sphingobacterium gen. nov. and Cytophaga johnsonae. FEMS Microbiol. Lett. 13:87-91.

28. Yabuuchi, E., E. Tanimura, A. Ohyama, I. Yano, and A. Yamamoto. 1979. Flavobacterium devorans ATCC 10829: a strain of Pseudomonas paucimobilis. J. Gen. Appl. Microbiol. 25:95-107.

29. Yano, I., S. Imaizumi, I. Tomlyasu, and E. Yabuuchi. 1983. Separation and analysis of free ceramides containing 2-hydroxy fatty acids in Sphingobacterium species. FEMS Microbiol. Lett. 20:449-453.

30. Yano, I., I. Tomiyasu, and E. Yabuuchi. 1982. Long chain base composition of strains of three species of Sphingobacterium gen. nov. FEMS Microbiol. Lett. 15:303-307. 